\title{
THE TWENTY-FIVE JOYS OF OUR LADY AN ENGLISH MARIAN ROSARY OF THE FIFTEENTH CENTURY FROM BODLEIAN LIBRARY MS DON. D. 85
}

\author{
BY JOHN C. HIRSH
}

"The Twenty-five Joys of Our Lady" is a study, examination, and critical edition of an unpublished fifteenth-century Middle English prose devotion preserved in Bodleian Library MS Don. d. 85. It is here associated with twenty-five "Joys of Our Lady" and presented as a vernacular Marian rosary, the first such to be identified in the period. The introduction to the edition considers early liturgical influences upon what became the tradition of Our Lady's Joys, their late-medieval development both across Europe and across England, and the circumstances that usually indicated fewer in number than is present in the devotion printed here. The introduction also concerns itself with the presence and practice of the rosary itself in late-medieval England and elsewhere and the limited evidence that has come down to us for its presence and circulation in England, including woodcut evidence in Caxton and allusions in other Latin devotions. It further indicates an ambiguity in this devotion's treatment of Christ's passion and concludes by considering the role and importance of joy as a pervasive, if often ignored, Christian attitude present in late-medieval English devotion.

Among its more recent acquisitions, the Bodleian Library, Oxford, preserves two late fifteenth-century English parchment manuscripts, now bound as one and thus purchased at Sothebys on 16 October 1945, lot number 2076. The single volume is now designated MS Don. d. 85, and preserved in the Bodleian's new Weston Library. ${ }^{1}$

The manuscript measures $240 \times 165(160 \times 100) \mathrm{mm}$ and contains ii +169 folios. It is bound in russia leather and bears the arms of M. Wodhull on the front cover. The first of the two manuscripts contains ii +1 to 90 folios and includes a calendar followed by a psalter, canticles, and a litany and is notable for a series of elegant historiated initials, many now badly damaged, most of them depicting David in various poses and attitudes: in prayer, standing, struggling in the water, and striking bells. It also presents historiated initials of the

1 The typescript catalogue for recently acquired medieval manuscripts in the Weston Library Reading Room notes that the manuscript's “owner [was] probably Oliver Whetenal, Vicar of Besthorp, Norfolk in 1445." It is possible that the name "Wetenale," which appears at the very end of the devotion, may be that of the author. By whomever inscribed, and though evidently a copy, this seems to be the first medieval rosary known to have originated in England. I am most grateful to the Bodleian Library, Oxford, for permission to publish this text as well as to Professor Mary C. Erler of Fordham University and to an anonymous reader for this journal for helpful comment on this study. 
Trinity, of saints associated with certain of the prayers, and other religious images. $^{2}$ It includes as well a number of separate and unconnected Latin prayers and religious verses, as does the second manuscript. The second manuscript, contained on folios 91 to 169 , presents selected parts of a missal, a litany of the Blessed Virgin Mary, and, toward the end, a series of prayers and devotions, including the only English item in the manuscript and the one that will concern us here, "The Twenty-Five Joys of Our Lady," preserved on folios 126-28, which I shall argue constitutes a hitherto unknown English Marian rosary, the only one to have come down to us from the late-medieval period. Both manuscripts evidently enjoyed liturgical usage earlier in their histories but, bound as one, seem to have been adapted for devotional use. ${ }^{3}$

The tradition at the root of the text that will engage us here sprang, directly and indirectly, not only from one understanding of the late-medieval rosary, but also from a number of related prayers and associated practices known as the (usually five or seven) "Joys of Our Lady," a tradition which reaches back to the second half of the seventh century, when four or more Marian feasts, celebrated since the fifth century in the Eastern church, made their way west. These included the Feast of the Purification (2 February), the Annunciation (25 March), the Assumption (15 August), and the Nativity of the Blessed Virgin (8 September). These liturgical feast days and their associated practices informed a wide variety of Latin hymns and hymns to Mary that transformed the Latin liturgy, adding elements of joy and celebration to practices focused more often upon Christ's passion and death. ${ }^{4}$

2 On the illuminations in this manuscript, see Otto Pächt and J. J. G. Alexander, Illuminated Manuscripts in the Bodleian Library, Oxford, 3 vols. (Oxford, 1973), 3:71, and plates LXXVI, 803 a, c, d, and LXXVII, 803 b, e. Sadly, none of these illuminations is connected to our text.

3 It is all but impossible to be sure how far the rosary, whatever is understood by that word, was known in England in the fifteenth century, where the early presence of prayer beads is well attested, however, and seem to have had a variety of largely undocumented devout uses. Paul Needham rightly remarks that "information on rosary practice in [medieval] England is close to non-existent," though he also points out its English diffusion in the Sarum Horae and elsewhere. See "The Canterbury Tales and the Rosary: A Mirror of Caxton's Devotions?" in The Medieval Book and a Collector: Essays in Honour of Toshiyuki Takamiya, ed. Takami Matsuda, Richard A. Linenthal, and John Scahill (Cambridge, 2004), 313-56, at 327n14; and Appendix A, "The Rosary in Printed Sarum Horae," in ibid., $342-47$.

4 The most effective overview of medieval liturgical hymns generally remains Guido M. Dreves, Clemens Blume, and H. M. Bannister, eds., Analecta hymnica medii aevi, 54 vols. (Leipzig, 1889-1922). On the images of Our Lady in liturgical feasts, e.g., see (1900) 34:68-71, nos. 76, 77, and 78, and 75-78, nos. 84, 85, 86, and 87. The hymns in Dreves 
Over time, each feast developed hymns to celebrate specific events in Mary's life, sometimes emphasizing her role as coredemptrix, sharing in Christ's suffering so as to become mediator between God and humankind and so capable of aiding in, even of bringing about, the salvation of certain of those who pray to her. These hymns often address Mary joyously, so that the direct greetings Salve and Ave that open hymn after hymn sound an almost personal note and anticipate a joyous outcome to the events described. Thus, even when the imagery associated with her traditional titles appears — stella maris, virgo gloriosa, Dei genetrix, medicina salutaris - their implicit gravity is balanced by a sense of celebration that anticipated the late-medieval Joys of Our Lady and eventually the countless adumbrations that appeared in the theology, art, liturgy, literature, and especially the devotion of the fourteenth and fifteenth centuries. ${ }^{5}$

These Marian "Joys," known across Europe by the fifteenth century, were originally five, though circumstances arose that led to an increase in their number, in the course of which certain Anglo-Norman examples were almost certainly inscribed by women authors. ${ }^{6}$ In Britain, the Joys of our Lady were usually

and Blume both reflected and made popular the images of Mary that circulated in the late medieval period and that informed devotions like this one. See F. J. E. Raby, A History of Christian-Latin Poetry from the Beginning to the Close of the Middle Ages, 2nd ed. (Oxford, 1953); and J. Szövérffy, Die Annalen der lateinischen Hymnendichtung: Ein Handbuch, 2 vols. (Berlin, 1964-65). On the development of Marian traditions in the early Church see: Averil Cameron, "The Cult of the Virgin in Late Antiquity: Religious Development and Myth-Making," in The Church and Mary: Papers Read at the 2001 Summer Meeting and the 2002 Winter Meeting of the Ecclesiastical History Society, ed. Robert N. Swanson (Woodbridge and Rochester, 2004), 1-21; Walter Berschin, "Early Medieval Latin Poetry of Mary," in ibid., 112-25; and Mary Clayton, The Cult of the Virgin Mary in Anglo-Saxon England, Cambridge Studies in Anglo-Saxon England 2 (Cambridge, 1990), chap. 2, "Feasts of the Virgin: Origin and Development," 25-51, and chap. 3, "The Cult of the Virgin in the Liturgy," 52-89. See further G. G. Meersseman, Der Hymnos Akathistos im Abendland, 2 vols., Spicilegion Friburgense 2 and 3 (Freiburg, 1958-60), 2:276-87 for a treatment of Eastern origins of certain Western Marian texts and a useful Mariological glossary.

${ }^{5}$ In the late medieval period these religious and liturgical elements combined with secular ones, and these have been recently examined by David J. Rothenberg, The Flower of Paradise: Marian Devotion and Secular Song in Medieval and Renaissance Music (Oxford and New York, 2011). But even when secular influences were present, devout ones usually prevailed. For an encompassing examination of devotion to Christ and Mary in this earlier period, see Rachel Fulton, From Judgment to Passion: Devotion to Christ and the Virgin Mary, 800-1200 (New York, 2002), 205-44. Rosemary Woolf argued that English devotion to Mary's Joys began in the twelfth century, spread throughout the thirteenth, and appeared in lay devotion during the fifteenth. Rosemary Woolf, The English Religious Lyric in the Middle Ages (Oxford, 1968), chap. 4, "Lyrics on the Virgin and her Joys," 114-58, especially $136-43$.

6 It is possible to attach the writing, and sometimes the authorship, of certain devotions, including this one, to women, particularly when they appear in devotional manuscripts or Books of Hours. Charity Scott-Stokes points out that "the possibility of female authorship may be conceded ... for the specifically feminine Anglo-Norman celebrations of the Joys of 
five or seven in number so that the extraordinary assemblage of twenty-five Joys contained in MS Don. d. 85 far exceeds the usual quota and suggests that this particular devotion had an equally particular purpose. The twenty-five Joys present here constitute both a devout narrative of the Virgin's life and afterlife and a celebration of her devotion to her Son, whose precedence is always respected. In doing so, they offer a form of guidance to the prayerfully reflective practitioner, enjoining him or her not only to recall the main events of Mary's life and afterlife but also to reflect upon them while offering an Ave as each one is recalled. The repeated phrase "In pe worschip of" enjoins the Ave that is to be recited after each event is recalled and forms part of a continuing series of connected prayers.

As I have already indicated, this narrative and these prayers, taken together, seem to represent an alternative version of the late-medieval rosary, which was only beginning to assume its final form, though this one, composed in English and dedicated exclusively to Our Lady, is complete in itself. Interestingly, there are no specific references to prayer beads in our text, and only the Ave Maria seems to have been envisioned as the prayer which, when repeated, would separate the individual episodes of Mary's life and advance the devotion. There is a precedent for this practice in the nearly contemporary York Horae, which contains a traditional "rosarium beate Marie" enclosing a Latin verse life of Our Lady, in which the four line stanzas that make up the life are punctuated by a total of fifty Aves and five Pater Nosters, which, taken together, constitute the rosary's five decades. The avoidance of the Pater Noster in our text seems to have been deliberate, no doubt intended to keep the focus largely on Mary. The individual episodes that make it up seem not to have been derived from any one devotion, however, and were probably constructed by our anonymous author him- or herself, evidently drawing upon more than one text. The rosarium in the York Horae offers unmistakable precedent for a Marian narrative that is central to an English devout text, and its description as a rosarium, I submit, further legitimizes my use of the word "rosary" to describe the largely unprecedented Middle English devotion printed below. The listing of twenty-five Joys in our text, each with an Ave following, suggests a grouping of five decades or chaplets, even without the addition of a Pater Noster after each group. The present form may have been influenced further by some knowledge on the part of the author of the kinds of prayers other rosaries were already beginning to employ or to his

Mary in the DuBois Hours," and, as she points out, the Joys of Mary often figure in such manuscripts. See her Women's Books of Hours in Medieval England, The Library of Medieval Women (Cambridge, 2006), 160, and nos. 3, 11, and 12.1 to 12.4 for citation of the Joys in manuscript; these range from five to fifteen in number, the same numbers that appear throughout fifteenth-century English lyrics. Among many, see Carleton Brown, ed., Religious Lyrics of the Fifteenth Century (Oxford, 1939; repr. 1962), nos. 30-31 (Five Joys), 34-36 (Seven Joys); and The Minor Poems of John Lydgate, ed. H. N. MacCracken, 2 vols., EETS ES CVII (Oxford, 1911; repr. 1961), 2:260-67 (Fifteen Joys). 
or her desire not to restrict the new devotion to those who were practiced in the use of beads.

What we have in MS Don. d. 85, I submit, is a complete if perhaps slightly truncated version of an English Marian rosary, preserved here in what has become a complex and elegant prayer book. It is quite possible, of course, that its exemplar might have contained references to beads or decades or both, which the author, scribes, or editor excised, preserving only the Aves as integral to the exercise, useful for separating episodes, and a part of the devotion that could be retained without creating confusion. This possibility becomes more likely if exact knowledge of the practices that constituted the rosary were still inchoate, so that our text gives evidence of a kind of Marian rosary that never finally took hold and indicates how the development of the rosary may have been a more complex process than is sometimes represented, replete with false starts, individual initiatives, and, as in this case, adaptations of existing devotions. In any case, the number of Joys that our text records, twenty-five, suggests five groups of five narratives, each one focused on the life of Our Lady and each with a prayer following, adapted from, or, as I have been suggesting, together constituting a hitherto unrecognized English Marian rosary. ${ }^{7}$

The interest of this text lies in the indication that an unknown author, evidently one who knew something of the early rosary, offered an alternative version to a still-developing tradition. Our author's text focused upon Mary's life and was made orthodox by its reference to the well-established tradition of her Joys, though it focused less upon theological mysteries than upon her widely known biographical narrative. His or her intention was plainly to offer spiritual guidance to the devout Christian by causing him or her to reflect prayerfully on the main events of Mary's life and to recite an Ave after each one. This rosary permits at least as much actual reflection as the one that developed under the direction of Alanus de Rupe (ca. 1428-1475), whose tract De Psalterio beatae Mariae Virginis: Exempla valde motiva ad amorem illius, finally printed in 1479 , both explained its

7 The York Horae is printed in Christopher Wordswoth, ed., Horae Eboracenses: The Prymer or Hours of the Blessed Virgin Mary according to the Use of the Illustrious Church of York with Other Devotions as They Were Used by the Lay-Folk in the Northern Province in the XVth and XVIth Centuries, The Publications of the Surtees Society (London, 1920; orig. pub. 1843), 132:142-47. The bibliography concerning the early history of the rosary is enormous, but see Anne Winston-Allen, Stories of the Rose: The Making of the Rosary in the Middle Ages (University Park, PA, 1997), including a useful summary of German scholarship. Winston-Allen treats Christ's biographical narrative, which the one of Mary presented here parallels; she also indicates the importance of praying aloud, even in private, in the medieval period, which in the case of the rosary treated here might have required a written text. See "The Significance of the Life-of-Christ Rosary," in ibid., 26-30, and "The Rosary and Spiritual Devotion," in ibid., 129-32. On the importance and practical use of numbers in prayers, see Rachael Fulton, "Praying by Numbers," Studies in Medieval and Renaissance History 4 (2007): 195-225. 
formation and influenced its transmission. ${ }^{8}$ The English rosary printed here, however, bears an interesting if indirect relationship to a much earlier yet curiously similar treatise by Stephen of Sawley (d. 1252), Meditationes de gaudiis beatae et gloriosae virginis Mariae. This extraordinary treatise, possibly intended for novice monks and thoughtfully examined by Matthew J. Mills, cites a total of fifteen Joys of Our Lady for use in meditation in groups of five, many of which parallel those preserved in the rosary and which, taken together, offer a life of the Blessed Virgin, punctuated by Aves and Pater Nosters. Mills indicates that it may have originated with the fifteen Gradual Psalms (Pss. 119-33) and have been intended for those in the early stages of the spiritual life who were acquiring an understanding of affective meditation, among other Cistercian practices. ${ }^{9}$ As such, it distinguishes itself from the text printed here, which certainly allows for a series of relatively simple meditations rooted in Mary's joy, ones that present themselves as astringent and formal and do not encourage their reader to relive either Christ's Passion or his mother's suffering. And yet the intellectual and spiritual coincidence of joy and narrative is present in each text, attesting to a continuing tradition of joy and celebration associated directly with the life of the Blessed Virgin. That both texts are associated with the rosary seems beyond doubt, particularly if we understand that the development of the rosary was not a simple descent like that of a

8 Alanus's influential text, written to formalize, but also to address, the structure of the rosary, has been attributed to its possible inventor, Dominic of Prussia (1384?-1460), and was included as an appendix to Michael François's Quodlibet de veritate fraternitatis Rosarii (1479) and, like others of Alanus's works, contributed to the development of the Confraternity of the Rosary and so to the form that the rosary took. See Luigi Gambero, Mary in the Middle Ages: The Blessed Virgin Mary in the Thought of Medieval Latin Theologians, trans. Thomas Buffer (San Francisco, 2005), 115-20 (from Maria nel pensiero dei teologi latini medievali [Milan, 2000]).

9 See Matthew J. Mills, "Stephen of Sawley's Meditations on Our Lady's Joys and the Medieval History of the Rosary," Cistercian Studies Quarterly 50 (2015): 426-39, commenting on the text printed in André Wilmart, Auteurs spirituels et texts dévots du moyen âge latin: Études d'histoire littéraire (Paris, 1932; repr. Études augustiniennes, 1971), 317-60; the quotation is from Mills, "Stephen," 439. Stephen's text seems early, but German rosary devotions are recorded as early as the fourteenth century; see A. Heinz, "Une forme ancienne du Rosaire au moyen âge chez les Cisterciennes de Saint-Thomas-sur-Kyll," Collectanea Cisterciensia 66 (2004): 140-52.

It may be worth pointing out that the addition, by Pope John Paul II, of a fourth decade into the modern rosary introduced not only a new theological but also a biographical dimension that, changes having been made, is present as well in the English Marian rosary printed here. In The Rosary of the Virgin Mary, an Apostolic Letter dated October 16, 2002, John Paul II introduced "The Luminous Mysteries of the Rosary," which he intended to follow the Joyful. They are: the Baptism of Jesus, the Marriage at Cana, the Proclamation of the Kingdom, the Transfiguration, and the Last Supper, all derived from Christ's (hitherto omitted) public life. Taken together with the fifteen other mysteries, they constitute a markedly Christocentric addition, and, though invoking his mother occasionally, now focus the rosary even more thoroughly upon a meditation on the life of Christ. 
manuscript stemma but one that, in Mills's words, "emerges gradually and under the influence of a number of traditions, including devotion to Our Lady's Joys." The particular devotion inscribed in MS Don. d. 85, though complete in itself and calling for a recollection of Mary's life in a way that would lead to adoration, meditation, and repeated prayer, also pointed the way toward later, longer versions that, informed by the printing press and tradition, would one day usurp the word "rosary."

There is one other aspect of this text that should be noted. It is remarkable that events directly relevant to Christ's passion, though unmistakably present in this rosary, are not emphasized and that the sections in which they occur are the three most problematic in the text as a whole. The relevant numbers are Joys sixteen, seventeen, and eighteen, though exceptionally none of these numbers actually appears in the text, and the only direct reference to Christ's passion and to Mary's associated suffering appears in what should be number sixteen, where it is recorded that, with Christ's appearance to Mary after his resurrection, the Virgin's "bytter sorwys" were turned to "perfyte ioye." This is followed by an almost passing reference to Mary's joy in Christ's Ascension into heaven, number seventeen, though again the number itself is not cited, and to the Descent of the Holy Spirit at Pentecost, where for a final time the number is missing. If these omissions are not simply due to a defective text, as is possible, then they may represent an intended effect, namely, to minimize or suppress the degree of Mary's cooperation in Christ's passion so that the extent of her role as coredemptrix would remain undetermined.

The English rosary printed here also offers an insight into an aspect of latemedieval spirituality that is not often discussed. The focus throughout, even when Christ's passion is alluded to, centers on Mary herself and on the several joys that were embedded in, and so gave meaning to, her glorious life. It follows traditional narratives that had received new emphases in lyrical and other forms of poetry, numerous lives of the Virgin, Books of Hours, and other prayer books, and also, in a less biographical way, in what became ten of the traditional mysteries of the rosary. These narratives, wherever present, were not generally, and certainly not necessarily, affective, and, though devotion of any sort can provoke religious sentiment in its practitioner, as a rule such narratives did not invoke affective awareness, fear of death, or extended meditation on Christ's passion.

Rather, they appealed to knowledge of and belief in what were understood to be Mary's joys both during her life and afterwards, so evoking a considered realization of the presence and importance of Christian joy, always an integral dimension of Christian spirituality. And, since for many late-medieval Christians the promise of individual salvation was the end and meaning of their religious life, the way to it, strenuous and demanding though it could be, was in the end entirely joyous. 
Thus a prayerful review of the life of the most perfect human being ever to have lived, and of the joys that accompanied that life, was an engaging and rewarding occupation and one that pointed the way toward salvation.

In the following edition, word spacing, punctuation, and capitalization have been modernized, though added commas have been bracketed. Bracketed capital or small letters [...] are the reverse in the manuscript, though I have preserved the readings: AUe maria, Ava maria, Aue maria, Ioye, and ioye throughout. Puncti before and after numbers have been retained, though unnecessary puncti elsewhere have been silently deleted. The Middle English letter forms thorn (b) for th, and yogh (3) for g, gh, and y, have been retained. Expanded abbreviations have been italicized. Manuscript paragraphing has been retained and foliation indicated. The joys described in numbers iij and iij, and the numbers, have been silently reversed.

[126r] Aue benignissima [I]hesu mater dei. [M]emento mei et Aue maria. In be worschep of be Ioye pat ze had when pat ze conseyued goddys sone porow be vertu of be $[\mathrm{H}]$ oly [G]ost Aue maria. In pe worschep of pe .ij. Ioye pat ye had when ze gret [S]eynt Elysabeth[,] and sche answered zou pat ze wer blyssed aboue al women[,] and pat pe frut of 3owr wombe. Aue maria. In pe worschep of pe .iii. Ioye pat ze had when pat ze felt goddys sone stere in zowre wombe. Ave maria. In pe worschep of pe .iiij. Ioye pat ze had when ze barr almyhty goddys sone wythowten peyne or trauayle[,] wyth more clennes and ioye pen any hert may thynkyn. AUe maria. In pe worschep of pe .v. Ioye pat ze had when ze saw lying afor $30 \mathrm{w}$ pe fairest forme pat euer was of mankynde[,] and ze worschepped hym as god \& goddys sone and 3owres[,] prayng to be fader of heuene pat ze myht kepe hys sone to hys most plesawnce[,] wyth al maner of mekenes. - - -

AUe maria. In pe worschep of pe .vj. Ioye pat ze had when ze behelde goddys sone lying [i]n 3owre lappe[,] and sokyng of 3owre virgynes melke. Ave maria. In be worschep of be .vij. Ioye pat ze had when pe schepherdys worschepped 3owre son as god [a]nd goddys sone after pe anuncia [126v] ciun of pe aungellys when pei songon Gloria in altissimus deo. AUe maria. In pe worschep of pe .viij. Ioye pat ze had when ze ofryd hym vp to [S]ymeon and fully affermyng pat he was goddys[,] wyth al gostly ioye seyde[,] Nunc dimittis. - - - -

AUe marie. In pe worschep of pe .ix. Ioye pat ze had when .iij. kynggys of [K] oloyn offryd to 3owre most blyssed sone [g]old[,] [e]ncense[,] [a]nd [m]yrre [i]n tokynnyng pat he was al mighty god[,] and hye kyng[,] and man born. Ave maria. In pe worschep of pe .x. Ioye pat ze had when ze browht yowre dere 
sone into Egypte. How ze knewe pat pe fals mawmentys fel down and brestyn. For dred of hys blyssed presenc. AUe maria. In the worschep of the .xj. Ioye pat ze had when ze fownde zowre sone in pe temple after pat ze had lost hym pre dayes. - -

AUe maria. In pe worschep of the .xij. Ioye pat ze had of be bapteme of yowre blyssed sone[,] when be $[\mathrm{H}]$ oly [G]ost lyht on hym in lyknes of a culuyr ${ }^{10}$ seynge pese wordys. Hic est filius meus dilectus. In quo michi bene complacium .....

AUe maria. In pe worschip of pe .xiij. Ioye pat ze had when ze knew in speryte how myhtyly goddys sone and zowrys had ouercome pe malys and temptaciun of pe fende porow pe myht of hys $[127 r]$ godhed. AUe maria. In the worschep of the .xiiij. Ioye pat ze had of the coming of 3owre bylssyd sone[,] when he had ben from 3ow .xl. dayes. AUe maria. In pe worschep of the .xv. Ioye pat ze had when ze saw 3owre sone begyne to preche and teche pe sauaciun of mannys sowle[,] [a]nd to kepe hys wordys contynualy in 3owr mynde. AUe maria. In be worschep of pe .xvi. Ioye pat ze had when ze sawe hym werk pe gret myraklys pat he wrowhte. AUe maria. In pe worschep of pe gloryows resurrectiun when he aperyd sodeynly to zow seyng[,] Salue sancte parens[.] [b]en wer al yowre bytter sorwys torned to perfyte ioye. -

AUe maria. In pe worschep of the mervaylus assenciun. AUe maria. In pe worschip of pe comyng down of pe [H]oly [G]ost[,] when he enlumyned jowr herte $[w] y t h$ more swetnes of grace pen any herte may thynkyn. AUe maria. In pe worschip of the .xx. Ioye pat ze had to vysyte and to worschep alle pe places pere 3owr blyssyd sone had conuersyd in hys benyng. Aue maria. In pe worschep of pe .xxj. Ioye pat ze had when pe awngil browht yow tydyngges pat ze schold departe of pis lyf and come to 3owr sone[,] and toke 3ow pe palme in 3owr hande[,] [i]n toky [127v] nyng of zowr virginyte and of euer lestyng pes. AUe maria. In pe worschep of pe .xxij. Ioye pat ze had when ze saw be apostlys sodaynly browht afor $30 \mathrm{w}$ in a clowde to serue $30 \mathrm{w}$ at 3owr deyng. AUe maria. In the worschip of the .xxiij. Ioye pat ze had when zowr blyssed sone come wyth gret multitude of seyntys and awngellys and fette 3owre blyssed sowle owt off zowre clennest body and offryd hyt to hys hye fader of heuene. - -

AUe maria. In pe worschip of the .xxiiij. Ioye pat ze had when zowre blyssyd sone toke pat holy sowle and browht hyt to be body and toke bothe wyth hym body and sowle[,] and wyth al pe celestial court of heuene[,] and somtyd 3ow into hyest heuene and pere he crownd 3ow qwene of heuene[,] Lady of pe [W]erld[,] Empress of [H]elle[,] as [D]erest [D]owhter of pe [F] ader[,] [T]rewest [W]yf of pe $[\mathrm{H}]$ oly $[\mathrm{G}]$ ost$[$,$] worthy to be moder to [\mathrm{G}]$ oddys $[\mathrm{S}]$ one of $[\mathrm{H}]$ euene.

\footnotetext{
10 Culuyr, otherwise culfre, or culver: sb.: dove.
} 
AUe maria. In pe worship of pe .xxv. Ioye pat ze had to be holde pe bryht schynyng of hys godhed per ze may clerely se pat zowr ioye schal euer encrese of hym[,] pat ze schul neuer be weruyd[,] and how al heuenly creaturys wyth owtyn ende presyng hym and worschep[yng] hym and thankyng hym[,] seyng[,] sine fine dicentes. Saultus. Sanctus. [128r] Sanctus. Dominus deus sabaot. Pleni sunt celi et terre maiestatis glorie tue. Amen. Wetenale.

\section{Georgetown University}

Keywords: vernacular rosary in English, medieval-English rosary, The Joys of Our Lady, Joy as a devout attitude, English-Marian devotion 